\title{
TUFFISITIC KIMBERLITE FROM EASTERN DHARWAR CRFATON, UNDRALDODDI AREA, RAICHUR DISTRICT,KARNATAKA, INDIA
}

\author{
J.N. Das ${ }^{1}$, M.M Korkoppa ${ }^{1}$, Fareeduddin ${ }^{1}$, S. Shivanna ${ }^{2}$, J.K. Srivastava ${ }^{3}$ and N.L.Gera $^{4}$ \\ 1. PPOD Division, GSI, SR, Bangalore; 2. Coal Wing (M-2B), GSI, Kolkata. 3. OP: Maharashtra, GSI, Pune, 4. SU: K \& G, GSI, \\ Bangalore
}

The Neoarchaean Eastern Dharwar Craton hosts number of both diamond and non-diamond bearing kimberlite bodies distributed in two major clusters viz Wajrakarur-Lattavaram Kimberlite Field in Anantapur district and Maddur-Narayanpet Kimberlite Field in Mahaboob Nagar district in the state of Andhra Pradesh. Almost all of these kimberlites are dated at $\sim 1.1 \mathrm{Ga}$ and represent root zones of hypabyssal facies kimberlites. The Undraldoddi kimberlite body (trendingWNW-ESE) located at about $0.75 \mathrm{~km} \mathrm{SW}$ of village Undraldoddi (16 $08^{\circ} 35^{\prime \prime}: 77^{\circ} 28^{\prime \prime} 40^{\prime} ; 56 \mathrm{H} / 8$ ) and $15 \mathrm{~km} \mathrm{SE}$ of Raichur in northern parts of Karnataka is part of a cluster of five kimberlite bodies in the newly discovered Raichur Kimberlite Field of South Indian Diamond Field (SIDF), situated mid-way to above two well-known kimberlite fields. The body was first reported during reconnaissance stage (UNFC G-4) investigation carried out by Geological Survey of India in Raichur area.

Kimberlite is emplaced at the contact between grey and pink biotite granite of Peninsular Gneissic Complex (Fig-1). It is a concealed body capped by 1 to $1.5 \mathrm{~m}$ thick calcrete below the topsoil but can be located in a number of dug well sections. .The rock is highly weathered, soft, friable, tuffaceous at places and greenish yellow/yellowish green in colour. Undraldoddi kimberlite with an aerial extent of over 10 ha is the largest of the kimberlites so far discovered from Karnataka. Panned concentrates of the weathered kimberlite yielded chrome spinel, chrome - diopside, garnet, phlogopite, perovskite, enstatite and zircon, of which the first three are in greater abundance. Presence of diamond in this pipe is yet to be tested. Drilling of 241.00 metres was completed in three boreholes (UD-1, UD-2 and UD-3) to establish its sub-surface geometry and to identify different pulses of kimberlitic intrusion (Shivanna,
2008). This paper provides the results of petrographic studies of the kimberlite body based on optical and electron-probe studies of the drill core samples.

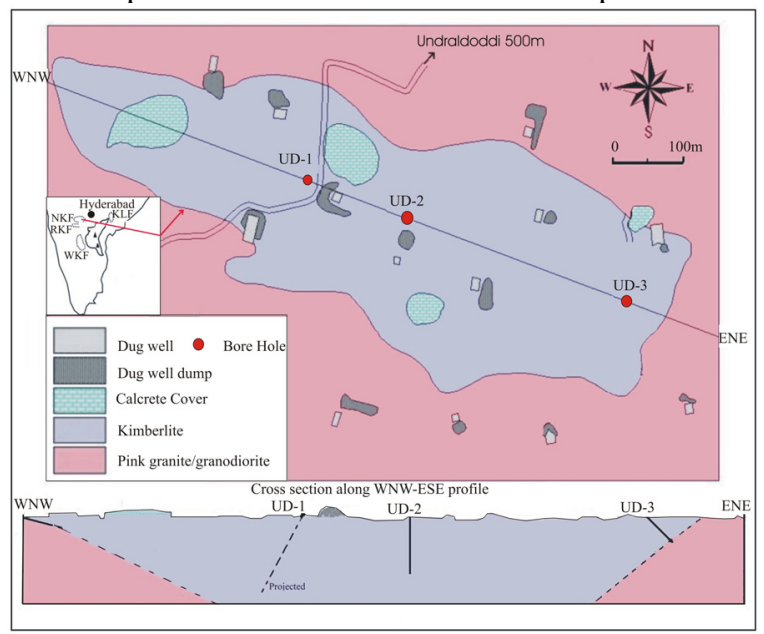

Figure-1: Detailed geological map of Undraldoddi Kimberlite body with drilling locations and cross section Modified after Shivanna, 2008).

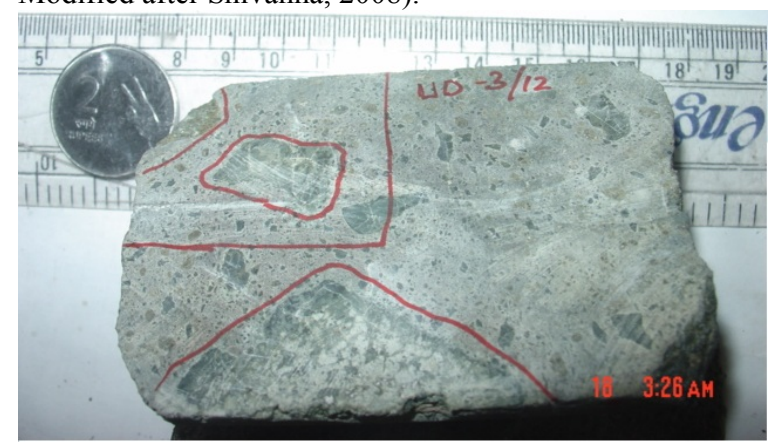

Figure-2: Inequigranular, macrocrysts texture defined by olivine macrocrysts in a grayish green ground mass of olivine, serpentine, carbonates and opaque.

The rock shows unsorted clast-supported textures (Figure-2) with (1) abundant anhedral macrocryst to microcrysts and smaller subhedral micro-phenocrysts 
of altered olivines; alteration phases are represented by chlorite-chlinochlore/smectite and rarely serpentine and often carry inclusions of spinel and nickel sulphide; rarely carbonates, phlogopite and diopside are present in some of the macrocryst (Figure-3c); (2) mantle xenocrysts (spinel, phlogopite, garnet, ilmenite) \& (3) mantle xenoliths, (4) 0.2 to $2 \mathrm{~mm}$ size sub-spherical to sub-ellipitical magmaclasts (pelletal lapilli) composed of either a kernel of altered olivine (Figure-3A) or rare ultramafic xenolith (Figure-3b) with distinct rim of very fine grained material; such rims carry microcryst/micro-phenocryst of pseudomorphed olivines set in a ground mass of chlorite-serpentine, spinels, rare apatite, phlogopite and irresolvable mineral phases and (5) minor country rock xenoliths (6) very fine grained inter clast matrix dominated by chlorite and serpentine. Such rims carry all the above clasts and have developed cryptocrystalline mantle of variable thickness with development of microlites of diopsides and mass of again irresolvable mineralogy (Figure-3c). The inter-clast matrix (ICM) is mainly composed of chlorite-serpentine with fine grains/crystals/aggregates of diopside and opaque. Presence of primary carbonates is rare. Crustal xenoliths are limited to contact regions of kimberlite with the granites.

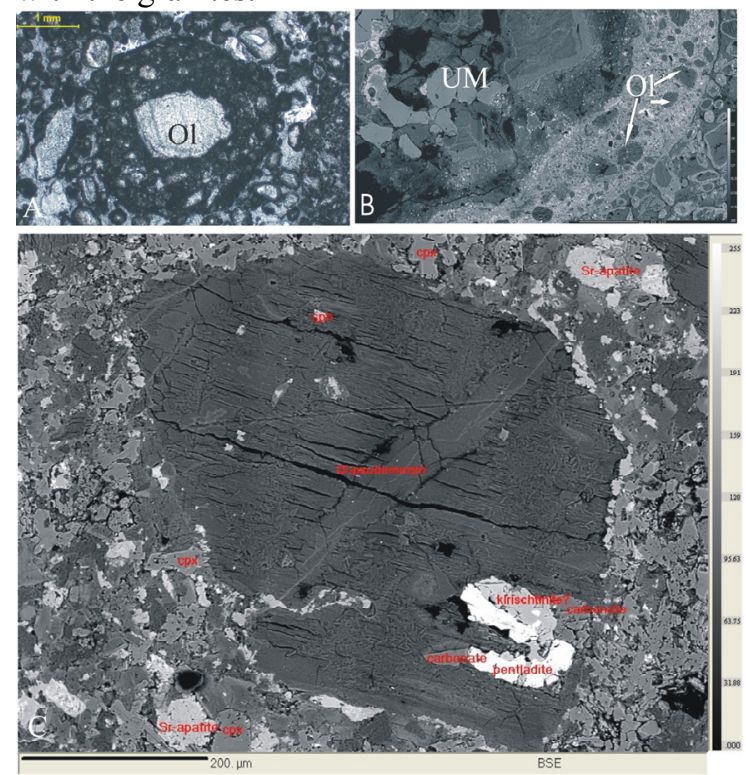

Figure-3: Typical magmaclasts (earlier pelletal lapilli) with distinct mantle of protolith kimberlite (A) kernel of pseudomorphosed olivine (Ol) PP. (B) Kernel of ultramafic xenolith (UM). Cryptocrystalline rim around macrocrytic olivine. BSE Image. (C) Olivine pseudomorph with inclusions of NiS, carbonate, and clinopyroxene. Note presence of Sr-Apatite at SW and NE corners. BSE Image.

Under electron beam the olivines have been completely pseudomrphosed to chloritechlinochlore/smectite assemblages with very little indication of serpentinisation. Inclusions of spinel, nickel sulphide phases (Figure-3c) and secondary development of carbonates, phlogopite and diopside are present in some of the macrocryst pseudomrphosed olivines. The groundmass within the magmaclasts is composed of fine prisms/equant grains of diopside, laths of phlogopite (altered to chlorite), minute grains of $\mathrm{Cr}-\mathrm{Al}-\mathrm{Mg}$ spinel, perovskite with frequent rim of sphene/titanite, rare apatite in mesostasis of chlorite-smectite. The development of diopside in the ground mass and sphene/titanite as alteration rim over spinel \& perovskite is ubiquitous and appears to be primary. The cryptocrystalline mantle of variable thickness either over macrocrystic olivine/xenocrysta (Figure4) or magmaclasts has distinct development of fine laths of diopside, flakes of chlorite-smectite, phlogopite, rare Sr-apatite with dispersed sphene/titanites phases. The ICM is mainly composed of randomly oriented flakes of chlorite/smectite with subhedral equant/microlite/fine-aggregates of diopside and minute grains of peroskite (altering to sphene), phlogopite and rare apatite. 


\section{$10^{\text {th }}$ International Kimberlite Conference, Bangalore - 2012}

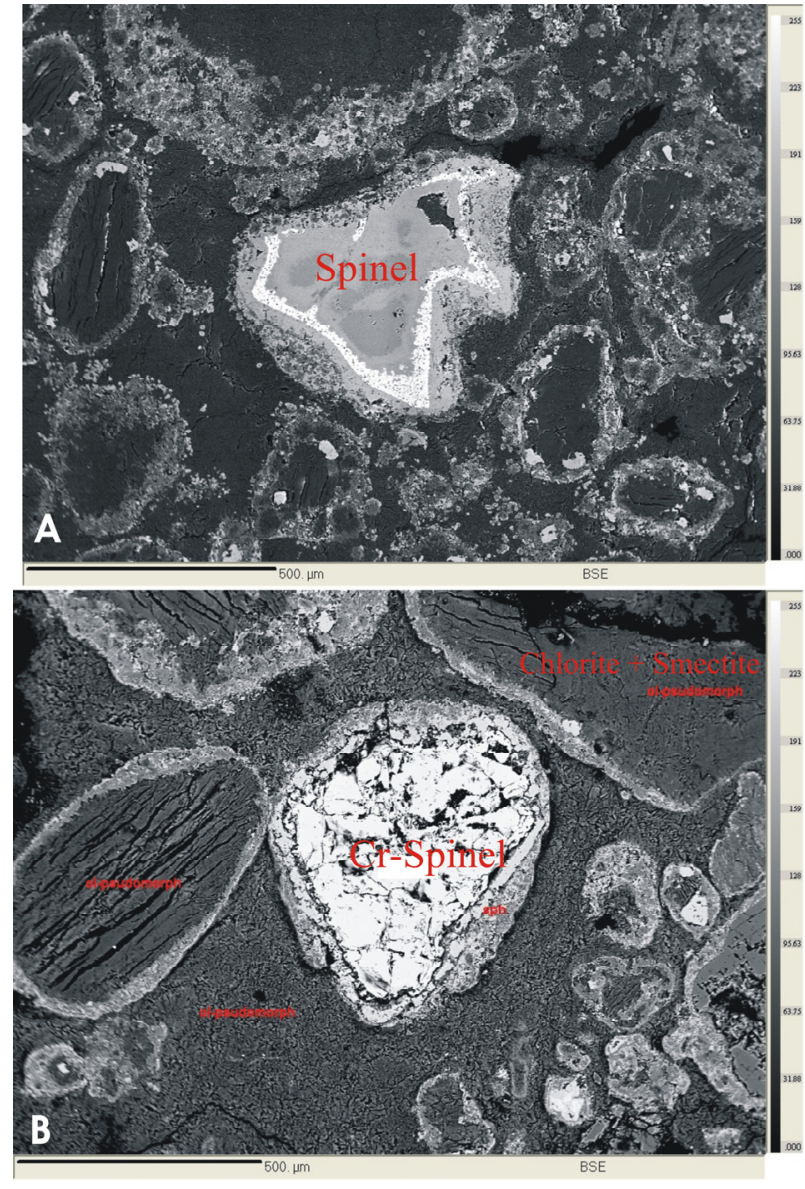

Figure-4: Typical cryptocrystalline mantle over olivine macrocrysts and spinel xenocrysts (UD-1/6 and 1/7). BSE Images

A review of the mineral content and composition reveals that except spinels all the original components like olivine, mica, perovskite have been altered. The olivine alters to chlorite-smectite aggregates, phlogopite to chlorite, perovskite to $\mathrm{Ca}$ Ti silicate (sphene). The development of new mineral phases like diopside, sphene and chlorite in all the samples are the characteristic features. The majority of the spinels (both xenocryst and groundmass phases) analyses are classified as high-chromium spinel (chromite), Al-Mg-Cr spinel with a growth rim of ulvospinel magnetite and magnetite. Interestingly an andradite phase (?) develops at the expense of AlMg-Cr spinels. All the spinels plot in T-1 trend of the kimberlite in the front face of the reduced ion spinel prism. The high chromium chromite (xenocryst) with $\mathrm{Cr}_{2} \mathrm{O}_{3}$ ranging from $55-59 \%$ falls very near to diamond stability field indicating deep source. The
REE pattern of these samples is similar to the kimberlite trend. (Figure-5)

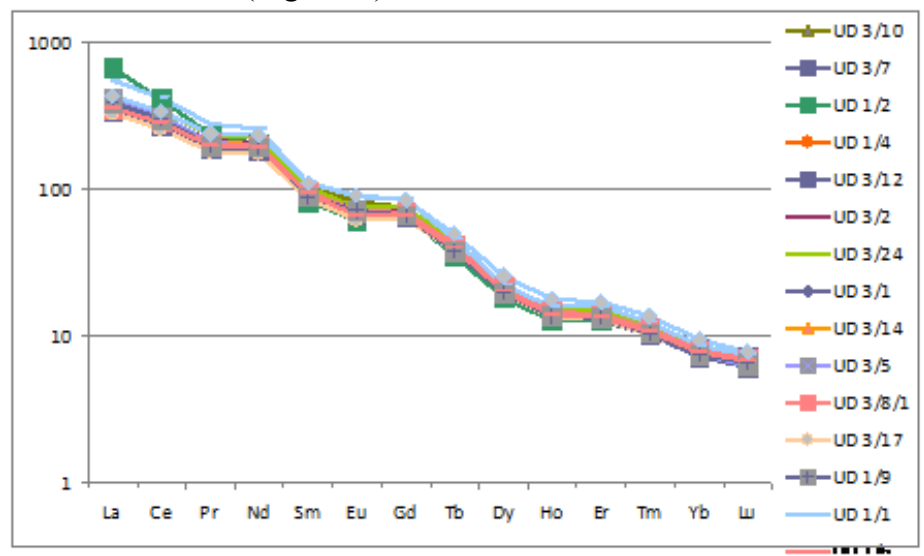

Figure-5: REE pattern of Undraldoddi kimberlite

The above studies suggest the Undraldoddi body possess distinct kimberlite mineralogy and its textural features suggest it to be a tuffisitic kimberlite (TK). This kimberlite shows remarkable similarity to the tuffisitic kimberlites of diatreme zone reported from South Africa (Mitchell et al-2009). This find of TK in eastern Dharwar Craton opens up new vistas in kimberlite research.

\section{Reference}

1. GSI-

http://www.portal.gsi.gov.in/gsiDoc/pub/DI D\%20Damond\%20final Final new.pdf

2. Mitchell.R, Skinner, E. Michael W, Scott Smith, Barbara H (2009)- Tuffisitic kimberlites from the Wesselton Mine, South Africa: Mineralogical characteristics relevant to their formation, Lithos, Volume 112, Supplement 1, November 2009, Pages 452-464, Proceedings of the 9th International Kimberlite Conference .

3. Shivanna,S (2008)- delineation and identification of pulses of intrusion and petrological studies of Undraldoddi Kimberlite, Raichur district, Karnataka, Progress Report for the Field Season 20032004, GSI, Project Diamond, Bangalore. 